\title{
TRANSITIVITY ANALYSIS OF AFGHAN WOMEN IN ÅSNE SEIERSTAD’S THE BOOKSELLER OF KABUL
}

\section{Arina Isti'anah}

arina@usd.ac.id

Universitas Sanata Dharma

Yogyakarta, Indonesia

\begin{abstract}
Transitivity analysis is the tool offered by Halliday's Systemic Functional Grammar (SFG) to observe the writer's/speaker's experience of the real world. In the novel entitled The Bookseller of Kabul, Åsne Seierstad's description of Afghan women reveals how they are represented in the story. By observing the different characters in the novel, this research focuses on outlining three different woman character roles; wife (Sharifa), mother (Bibi Gul), and daughter (Leila). The stylistic approach focusing on the grammatical features is utilized in this research. The writer's descriptions of Sharifa, Bibi Gul, and Leila are categorized into the transitivity processes adopting Halliday's SFG. The analysis shows that different woman roles are represented in similar processes: material, mental, relational, verbal and behavioral. The processes reveal that Afghan women are represented as submissive and devoted characters. Behavioral process is only used to reveal the characters' being submissive, while the material process is employed the most to portray Afghan women's devotion to the family.
\end{abstract}

Keywords: Afghan woman characters, transitivity

\section{INTRODUCTION}

Language enables people not only to communicate, but also to show identity. Gee asserts that language is used so that we are recognized as taking on certain identity or roles (2005). Identity is revealed through language choice by its speaker/writer. The identity meant here is not only referred to the speaker's/writer's identity, but also how the speaker/writer embodies other's identity. Such way is presented in literary work.

Literary work, in this notion is novel, is narrated in either subjective or objective point of view. Verdonk (2002) asserts that the different pronoun used in literary work shows different perspective or point of view. Subjective pronoun $I$ shows the author's subjectivity, while the third person pronoun shows the author's objectivity. The objective way of narrating the story is an effective tool to portray the characters.

Language is presented as the system as well as grammar, so-called as lexicogrammar, as proposed by Halliday's Systemic Functional Grammar (Downing and Locke, 2006). Transitivity is one of the lexicogrammar category which enables us to analyze people's perception of the world through language choice (Gallardo, 2006). The perception can be represented purposefully or accidentally, found in the real world or imaginary events, whose information is gathered through information revealed from processes, participants and circumstances (Opara, 2012).

The Bookseller of Kabul is a novel written by a Norwegian journalist, Asne Seierstad, who published the novel after staying in an Afghan family. Her story once created debates since the identity of the family was uncovered. The experience of living in an Afghan family reflects how Seiesrtad observes the family, including the different gender roles: men and women. What is told in the story reflects that the husband has significant roles in the family, such as deciding the future of his daughters as well as sisters. 
What motivates the present research is the representation of Afghan women reflected by three different characters: Sharifa as the wife, Bibi Gul as the mother, and Leila as the daughter and sister of Sultan Khan. The author's narration becomes the primary data used as it is foregrounded. The transitivity analysis is significant since it discusses the foregrounded element of literary work (Brooks, 2009-2010).

Afghan women's inferiority appears in the novel (Andrews, 2016). As a reflection of the real world, the novel also portrays that Afghan women have less roles in the family. UNESCO records that women were slaves of their husband, father-in-law, and elder brother even until the beginning of 20th century. That situation shaped Afghan women as silent and obedient women's roles are around the home affairs involving their physical power (Rahimi, 1991). It is historically a fact that men have higher status than women.

The role of daughter is determined by the father. Daughters are raised to be good mothers and tolerant housewives. Therefore, education is ignored (Rahimi, 1991, p. 6). A wife's tolerance is enacted in the form acceptance when the husband decides to marry another woman. In the novel, Sharifa experiences such thing. She does not have any power to oppose her husband's decision. The representation of a wife, mother, and daughter to represent an Afghan women provokes this present research.

To criticize literary works by means of linguistics, stylistics offers a critical point of view by exploring particular levels of language (Beard, 2004). Quirk mentions that stylistics is "something like a revolution in the relation between linguistic and literary studies" (Ravassat \& Culpeper, 2011, p. 2). The existence of stylistics is not to oppose the findings of literary criticism, yet it provides alternative interpretation of the work.

The present research focuses on the grammatical level of analysis by employing transtivity analysis proposed by Halliday. In SFG, meanings are represented in three functions: ideational, interpersonal, and textual function. Each function has its own focus to reveal the significance of language choice to reveal the speaker's/ writer's purpose. SFG is rooted from the notion how language is used to "construe reality and enact social relationship" (Halliday \& Webster, 2009, p. 1).

Ideational meaning deals with how language users present their world experience through lexico-grammatical choice they make, part of transitivity system (Ezzina, 2015). Halliday \& Webster (2009) add that ideational function reveals the 'construing experience' seen from the structural configuration processes, participants and circumstances. On the other hand, interpersonal meaning concerns how language is used to enact social relationship (Halliday \& Webster, 2009). Textual function focuses on how the message is signposted in terms of Theme and information structure (Halliday \& Webster, 2009).

In the ideational meaning, the experience is reflected in the form of processes, participants and circumstances. It is mentioned that verbal element is the core of clause, representing what is crucial in the rest of the clause (Jeffries \& Mclntyre, 2010). Transitivity is also a grammatical system which deals with various processes in the structure of language (Song, 2013).

There are six processes in transitivity: material, mental, relational, verbal, behavioural, and existential processes (Halliday \& Matthiessen, 2004). Table 1 summarizes the processes along with their participant.

\begin{tabular}{|c|c|c|c|}
\hline No & Processes & Meanings & Participants \\
\hline 1 & Material & $\begin{array}{l}\text { doing, } \\
\text { happening }\end{array}$ & Actor-Goal \\
\hline 2 & Mental & $\begin{array}{l}\text { feeling, } \\
\text { thinking }\end{array}$ & $\begin{array}{l}\text { Senser- } \\
\text { Phenomenon }\end{array}$ \\
\hline 3 & Relational & $\begin{array}{l}\text { classifying } \\
\text { identifying }\end{array}$ & $\begin{array}{l}\text { Carrier- } \\
\text { Attribute } \\
\text { Token-Value }\end{array}$ \\
\hline 4 & Verbal & saying & $\begin{array}{l}\text { Sayer-Verbiage- } \\
\text { Receiver }\end{array}$ \\
\hline 5 & Behavioral & behaving & Behaver \\
\hline 6 & Existential & being & Existent \\
\hline
\end{tabular}

Table 1 displays that each process brings different meanings, thus the participants requires are also different.

Studies applying transitivity analysis have been exercised previously. Brooks utilized transitivity to observe the South African apartheid in Van Wyk's "In Detention" by means of corpus stylistics (2009-2010). Nguyen observed the representation of mother in "Heroic Mother" by Hoa Pham (2012). 
Gusrayani worked on thematic and transitivity in children's songs and stories (2008). Transitivity analysis also reveals a character's role in a society reflected in the novel entitled The Voice (Boukari \& Koussouhon, 2018). Children story Pinnochio is also observed in terms of its verb degree (Pradnyadari et al., 2018). Those aforementioned studies agree that transitivity analysis is able to reveal the representation and roles of characters by observing the author portrayal of the characters.

\section{METHODOLOGY Method}

Stylistic approach is chosen as the most appropriate one since it provides the linguists to observe literary texts (Jayal,2013). In stylistics, there are some language levels to observe, one of which is discourse level. In this level, the researcher employs Halliday's transitivity analysis under Systemic Functional Grammar point of view (Halliday and Webster, 2009). Stylistics provides the systematic study of language description of literary works. The study will not only display the language feature description, but also figure out the effects resulted from the choice of words. In stylistics, transitivity analysis is believed to figure out the effects of particular choice (Koussouhun and Dossoumou, 2015). In this research, the effects are the roles of women in an Afghanistan society portrayed in the novel.

\section{Data Collection}

The main data are taken from a collection of novel entitled The Bookseller of Kabul by Åsne Seierstad. The novel was published by Back Bay Books in New York. The novel contains of 19 chapters. Of those chapters, the researcher selects the ones presenting the role of women. In other words, the extracts of the novel are purposively selected in the way they present different woman roles. "The Proposal" and "Crime and Punishment" are the two chapters involving Sharifa the most in the description. "The Matriarch" is the chapter describing Bibi Gul and "A Broken Heart" were chosen since it talked about Leila. By taking sample study, the analysis of the research is expected to represent the roles of different women in the story.

\section{Data Analysis}

The data are analyzed in some steps. First, the researcher selected particular chapters of the novel which describe the woman characters the most. There were four chapters describing Sharifa, Bibi Gul, and Leila. Second, the researcher sorted the narrator's utterances in describing the woman characters and categorize each utterance using transitivity analysis. Third, the researcher summarized the process types of transitivity which represented each character. By looking at the processes, participants, and circumstances in each clause, the researcher can figure out how the narrator portrays woman characters in the novel. Since there are three woman characters to focus, the researcher analyzed each character first, then find out the similarities and differences of each. Last, the researcher concludes the role of women in Afghanistan represented by the three characters by providing the hard data found in the novel.

\section{RESULTS AND DISCUSSION}

Table 2 summarizes the processes employed in the novel to describe woman characters. There are three women to observe; Sharifa (wife), Bibi Gul (mother) and Leila (daughter).

Table 2. Summary of Transitivity Analysis in the Novel

\begin{tabular}{lccc}
\hline Processes & $\begin{array}{c}\text { Sharifa } \\
\%\end{array}$ & $\begin{array}{c}\text { Bibi Gul } \\
\%\end{array}$ & $\begin{array}{c}\text { Leila } \\
\%\end{array}$ \\
\hline Material & 34 & 27 & 46 \\
Relational & 7 & 6 & 21 \\
Mental & 9 & 17 & 22 \\
Verbal & 3 & 0 & 10 \\
Behavioral & 3 & 2 & 6 \\
Total & 56 & 52 & 105 \\
\hline
\end{tabular}

Table 2 shows the same pattern used to represent women regardless their roles. The three woman characters in the novel are represented by material process the most. The verb in material process tells about an action, while the noun groups represent the thing which does the action and the thing which is on the receiving end of the action (Lock, 1996, p. 72). The following parts represent each woman character in the novel; Sharifa, Bibi Gul and Leila. 


\section{The Representation of Wife}

The extract below is taken from the first chapter of the novel, The Proposal. In the beginning of the novel, Seierstad tells about the plan Sultan Khan has made to propose a young girl to be his second wife. This is the power of man in Afghanistan to arrange his marriage. In Islam, men are allowed to have more than one wife. It is also represented in The Proposal. The research is more interested in describing how the firs wife, Sharifa, is represented in the novel. Seierstad chooses material process the most to represent Sharifa. The extract below is the example.

Sharifa was getting old. Like Sultan, she was a few years over fifty. She [Actor] had borne him [Receiver] three sons and a daughter [Goal]. The time had come for a man of Sultan's standing to find a new wife (Seierstad, 2004, p. 4)

This is women's special ability to give birth to their children. The material verb borne is chosen in the novel to tell the readers that as the first wife, Sharifa has given four children to the husband, Sultan Khan. It is not because of Sharifa's inability to give him children, but the husband's power and prestige to choose another woman to be his second wife. In the last sentence of the extract above, Seierstad also notices that men over fifty are common to find another woman.

What is interesting in the first chapter of the novel is that Sultan Khan did not tell his wife and family that he would propose a sixteen-year-old girl named Sonya. $\mathrm{He}$ managed the proposal himself. This condition makes his wife and the family shocked. Usually, the mother and sisters would arrange a marriage of the man in the family. However, that situation is not found in Sultan Khan's choice. The extract below shows the response of Sharifa, the wife.

Sultan went home to inform his family of the news. His wife, Sharifa, his mother, and his sisters were seated around a dish of rice and spinach. Sharifa [Senser] thought he was joking [Phenomenon] and laughed and cracked some jokes in return (Seierstad, 2004, p. 7).

The fact that Sultan Khan was about to marry a young woman was never imagined by Sharifa. The mental verb thought shown in the extract above reveals that Sharifa involves her cognition about the news brought by her husband. That is, why Sharifa responded it by laughing which is included as a behavioral process. This process involves both material and mental. The following response given by Sharifa's cracking some jokes, a material process, showing an action by Sharifa to deny the fact she just knew.

When the engagement day comes, Sultan asked Sharifa, his mother and sisters to attend the event. He intends to show Sonya's family that the wife and whole family supports him. As a wife, Sharifa is represented in a material process as the Actor who conducts particular action for the sake of her husband.

Twenty days after the proposal of marriage the solemn engagement ritual took place. Sharifa [Actor] pulled herself [Goal] together [Circumstance of manner] and put on a brave face [Goal]. (Seierstad, p.8)

The material verb in the above extract is done by Sharifa in a situation that forced her to do so.

To accept the fact that her husband is about to marry a young girl upsets Sharifa. Sharifa is attached to sadness shown by relational process. The extract below is the proof.

Sharifa [Carrier] was inconsolable [Attribute]. What really rankled was the fact that the man had picked an illiterate, someone who had not even completed nursery school. She, Sharifa [Carrier], was a qualified Persian language teacher [Attribute]. "What has she got that I haven't got?" she sobbed (Seierstad, p.7).

The first sentence in the above extract takes Sharifa as the carrier and inconsolable as the attribute. Sharifa is the noun attached to adjective inconsolable as the attribute. As a wife, Seierstad portrays Sharifa as a sad wife having to accept the fact that her husband picked someone who does not belong to the same class as her. The extract above obviously portrays that Sharifa is an educated person. The third sentence takes Sharifa as a carrier and a qualified Persian language teacher as attribute. Since the attribute is in the form of noun group, it means that Sharifa is referred to the class of entity which the carrier belongs.

With the backup of the family, Sharifa shows her action by refusing to attend the wedding ceremony. It is shown in the following datum.

The wedding took place two months after the engagement, on the day of the Muslim New Year's Eve. This time Sharifa [Actor] refused to attend [Goal] (Seierstad, p.8). 
The verb refused in the above extract takes Sharifa as the Actor. However, as a woman character, Seierstad portrays more about Sharifa in the next two chapter entitled Crime and Punishment.

Sharifa then lives separated from Sultan Khan and Sonya. In her life as the first wife, Sharifa is portrayed in different transitivity process. The most used process in the novel is material. Below are the examples.

Sharifa [Actor] sweeps the floors [Goal], washes curtains [Goal], busies herself [Goal] with the perpetual dusting [Circumstance of manner], sits down, sighs, sheds a few tears [Goal]. (p.24) Sharifa [Actor] cooked, served, washed, and make the beds [Goal] (Seierstad, p.25).

The above sentences are represented in material process with Sharifa as the actor. The bold words above mark material verbs, representing actions the actor does. Those verbs signify the house chores done by the wife. It is the wife's responsibility to manage things at home. The verb shed in the first sentence above shows Shafira's sadness of being the first wife who still takes responsibility of doing chores.

What is dilemmatic for Sharifa is that she has to perform her responsibility as a good wife instead of getting divorce from Sultan Khan. The data below show material process representing Sharifa.

She [Actor] swallowed her pride [Goal] and appeared the model wife. (p.25)

Sharifa tried to chirp like a fussing mother hen. She [Actor] took on the heaviest chores [Goal] and little by little taught Sonya how to make Sultan's favorite dish, showed her how he liked his clothes organized, the temperature of the water he washed in, and other details that a wife should know about her husband [Goal]. (Seierstad, p.26)

The verbs swallowed is a material verb with her pride as the patient. It is the constituent which receives the action. In the following sentence, the verb tried, took and taught are also material verbs with Sharifa as the actor. She is the constituent who conducts the actions, including teaching Sonya how to serve Sultan, their husband.

The actions done by Sharifa above results in some feelings experienced by Sharifa as presented in mental process. Below are the examples.
She [Senser] knows that Sultan will turn up one of these days [Phenomenon], but he can never be bothered to tell her exactly when he is leaving Kabul, so Sharifa [Senser] expects him home [Phenomenon] every hour for days on end [Circumstance of time]. (Seierstad, p.23)

The first sentence shown in the data above takes she, representing Sharifa, as the Senser. It takes a Phenomenon in the form of a noun clause that Sultan will turn up one of these days. Mental process in that sentence is marked by the verb knows categorized as cognitive process. Here, Sharifa involves her consciousness when she is waiting for her husband. Beside cognitive mental process, Sharifa is also represented in desiderative mental process marked by the verb expects. This kind of process shows Senser's wish. The extract above shows Sharifa's awareness and expectation to her husband.

Though Sharifa does not decide to divorce from Sultan, she cannot deny her feeling of betrayal. Below is the datum in mental process.

Sometimes she [Senser] hates him [Phenomenon] for having ruined her life, taken away her children, shamed her in the eyes of the world [Circumstance of reason] (Seierstad, p.24).

The verb hates in the above sentence is also categorized as emotive mental process. It refers to the Senser's emotion to the phenomenon. It is clearly seen that the Senser is Sharifa and the phenomenon is him, referring to Sultan Khan. Shafira blames her husband for the material actions he has done to her: ruining her life, taking away the children and shaming her in the eyes of the world. The actions mentioned previously creates emotion to Sharifa.

Another process to represent Sharifa is relational process. The sentences below are the examples.

Sharifa, the pensioned-off wife, is waiting in Peshawar. She [Carrier] has no peace [Attribute]. She knows that Sultan will turn up one of these days... (Seierstad, p.23).

The relational process in the above extract is shown by the verb has. Thus, the process is categorized as possessive relational process. Sharifa, represented in pronoun she is the possessor and no peace is possessed. This kind of process is to attach Sharifa with no 
peace. As a wife, she does not possess that kind of abstract thing.

The other relational process representing Sharifa is displayed in the following sentence.

She [Carrier] swallowed her pride and appeared the model wife [Attribute]. Seierstad, p.25)

The linking verb appeared functions to attach Sharifa as the Carrier to the Attribute the model wife. Despite peace that she does not get, Sharifa is attached as the model wife. She still takes care of households and she even teaches Sonya how to take care of their husband.

The next process to characterize Sharifa is behavioral process. It refers to a "borderline area between mental processes and material processes" (Downing \& Locke, 2006, p. 151). Sharifa [Behaver] sighs. She thinks of the punishment that befell her neighbor Jamila (Seierstad, p. 34).

Shafira [Behaver] sighs. Jamilla committed a serious crime, but more from ignorance than a wicked heart (Seierstad, p.36).

The verb sigh marks the behavioral process. The mental process refers to Sharifa's feeling towards her neighbor, Jamilla. What makes Sharifa sigh is the punishment given to Jamila, her neighbor who just died. Jamilla is a newly-wed whose husband left for work. During that time, her husband's brother found a man visiting Jamilla by finding out things belonging to the suspect. Since the family is so shamed of the situation, Jamilla's mother decides to ask his sons to kill Jamilla. It happens since a woman having an affair with another man is a disgrace to the family.

From the elaboration above, material verbs designated to Shafira is used by Seierstad to represent the household actions a wife does. Despite the feelings Sharifa has, which are represented in mental verbs, Seierstad portrays Sharifa as a tough woman. The onesided decision to marry a young girl made by her husband, Sharifa does not have any courage to leave her husband. Disgrace is attached to a divorced woman in Afghanistan. Thus, to maintain the family's dignity, Sharifa chose to stay and even she accepts Sonya, the second wife, eventually.

\section{The Representation of Mother}

Similar to Sharifa, Bibi Gul is also represented the most by means of material process. Bibi Gul is the mother of Sultan Khan.
Bibi Gul has given birth to thirteen children. When she was fourteen she had her first daughter, Feroza. At last life was worth living. She had cried throughout the first years as a child bride; now life was better.

In this research, the sample to analyze Bibi Gul is seen from the chapter "The Matriarch". The extract below is the example. A wedding is like a small death. The bride's family mourns in the days following the wedding, as though it were a funeral. A daughter is lost, sold or given away. The mothers [Actor] especially grieve. They have had complete control over their daughters, where they go, who they meet, what they wear, what they eat. They [Actor] have spent most of the day [Goal] together, got up together, swept the house together, and cooked together [Circumstance of manner] (Seierstad, p.106).

The material verbs used in the above extract are grieve, spend, get up, sweep and cook. The first material verb used has mothers in Afghanistan, including Bibi Gul. It is a common thing there that a mother will lose her daughter before the wedding. A mother will lose her responsibility since a marriage woman is under her husband's responsibility. A mother has no longer rights to control her daughter. A daughter is represented as the best partner for a mother since they do household activities together as seen in the following material verbs mentioned above.

Another example of material verb representing the mother character is displayed below.

Bibi Gul [Actor] doesn't do a lick of work [Goal] anymore [Circumstance of time]. She [Actor] sits in the corner [Circumstance of place], drinks tea [Goal], and broods. Her working life is over. When a woman has grown-up daughters, she [Actor] becomes a sort of warden who bestows advice, guards the family's morals-in practice, the morals of the daughters [Goal]. She [Actor] makes sure that they do not go out alone, that they cover up appropriately, that they do not meet men outside the family, that they are obedient and polite [Goal] (Seierstad, p.108).

The first three material verbs bold above represent the actions of a mother when she has grown up her daughters. An old mother does not longer have responsibilities to do the chores. She is taken care of by her youngest daughter, Leila. Bibi Gul has given thirteen children. Her youngest daughter is nineteen 
years old. A mother is represented as the Actor to take care of her daughter in relation to some goals. The verbs "makes sure" above emphasizes on the job that a mother must accomplish. The actor above takes some goals represented in noun clauses: "that they do not go out alone, that they cover up appropriately, that they do not meet men outside the family, that they are obedient and polite". Those goals refer to how daughters should behave and become.

The next example of material process portraying Bibi Gul is told by Seierstad in the following excerpt.

Mariam cried for three years. In the end [Circumstance of time] Bibi Gul and Karimullah's mother [Actor] decided that she must marry the deceased husband's brother, Hazim [Goal] (Seierstad, p.118).

Mariam is one of Bibi Gul's daughters who lost her husband when civil war came in Kabul. The mother has the power to choose a suitor for her daughter. In the above excerpt, Bibi Gul represents an Afghan mother who is responsible for her daughter's marriage. She chooses Mariam's deceased husband's brother to be her wife. The use of modal "must" also emphasizes power the mother has. It is obliged for a daughter to follow her mother's order.

The mother's responsibility and power are represented in the material process whose Actor is Bibi Gul. In the chapter, it is told that Bibi Gul found Farid a wife. Below is the extract. A few years after Sultan, Farid arrived. He was a mad cap who always got caught up in fights and came home with torn clothes and a bloody nose. He drank and smoked, of course without his parents' knowledge, but was good as gold when he was not angry. Bibi Gul [Actor] found him [Recipient] a wife [Goal] and now he is married with two daughters and a son. But he has been excommunicated from the apartment in block no. 37 in Mikrorayon. Bibi Gul [Behaver] sighs (Seierstad, p. 117).

In the extract above, Bibi $\mathrm{Gul}$ is represented as the Actor. The material verb is "found" which is ditransitive. Thus, it takes two participants which are recipient and goal. Farid, the son is presented as the receipient, an entity which receives an action by the actor. The goal above is "a wife" meaning the constituent which is directed to. In the above extract, Bibi Gul is also presented as a behaver marked by the behavioral verb "sigh".
In the novel, Bibi Gul is also portrayed as a loving mother. In the chapter, Bibi Gul recalls her children. When she memorizes her children, her tear drops. In the second sentence of the extract below, Bibi Gul is presented as the actor who conducts the material process "shed" which take the goal "a tear". Below is the extract.

After Farid came Shakila. Cheerful, tough, strong Shakila. Bibi Gul [Actor] sheds a tear [Goal]. She [Senser] visualises her daughter [Phenomenon], dragging heavy water buckets. Next was Nesar Ahmad. When Bibi Gul [Senser] thinks of him [Phenomenon] the tears start to flow (Seierstad, p.119).

In the extract above, Bibi Gul is also portrayed in a mental process. The mental verb "visualize" marks the process. The phenomenon is "her daughter" referring to Shakila. When Bibi Gul remembers Shakila's hard work when she was young, it hurts Bibi Gul's feeling. Another mental process is shown when Bibi Gul memorizes another son, Nesar Ahmad. Bibi Gul is also presented as the senser and "him" is the phenomenon. The extract above reveals Bibi Gul's affection and sympathy to her children.

The novel emphasizes the role of mother as the affectionate character in many ways. Below is the extract realized in mental process, too.

Bibi Gul [Actor] sheds another tear [Goal]. She [Senser] hates being far away from her children [Phenomenon]. They are all she has in life, apart from the glazed almonds at the bottom of the chest (Seierstad, p. 119).

Similar to the previous analysis, Bibi Gul is presented in both as actor and senser. The material process chosen by Seierstad is realized by the verb "sheds" and the goal is a noun phrase "another tear". The next process found above is mental, marked by the emotive mental verb "hates". The phenomenon is presented in the form of present participle "being away from her children". Again, Bibi Gul cries when she remembers her children.

In the following extract, it is told that Bibi Gul gave one of her children to her relative. Actually, it is hard for her to give in her child, yet she makes it. The material process below shows Bibi Gul's commitment to fulfill her promise to her relative. Below is the extract. In the end [Circumstance of time] Bibi Gul gave in and promised her [Recipient] the child [Goal]. 
When her son was born she kept him for twenty days [Circumstance of time] she [Actor] nursed him [Goal], cuddled him [Goal] and cried over having to give him away [Goal]. Bibi Gul [Carrier] was an important woman [Attribute] by virtue of her children [Circumstance of manner] (Seierstad, p. 120).

In the above extract, Bibi Gul is presented in mental process in order to show her cognition that her child is well cared by her relative. Besides, Bibi Gul is also narrated in relational process in order to attach her to particular quality. The attribute "an important woman" is chosen by Seierstad in order to show Bibi Gul's responsibility as a mother. She is portrayed as a tough and caring mother. Though she gives in one of her children, it does not mean that Bibi Gul does not love the child.

The extract below shows how Bibi Gul suffers from missing her child. However, she has decided to give in her child.

She [Senser] wanted as many as possible. But she [Actor] kept her promise [Goal] and after the agreed twenty days [Circumstance of time] she gave him [Goal] to the relative [Recipient], and though the milk flowed she [Actor] could not nurse him [Goal] again [Circumstance of manner]. All ties to the mother had to be severed and from then on he was only a relative. Bibi Gul [Senser] knows that he is well cared for [Phenomenon], but still mourns the loss of her son. When she meets him [Circumstance of time] she [Senser] feigns indifference [Phenomenon], as she promised when she gave him away [Circumstance of manner] (Seierstad, p. 120).

Having many children is not regarded as a burden for Bibi Gul. Instead, she seeks as many as possible, as seen in the mental process above, taking Bibi Gul as the Senser and "want" as the mental verb. Losing a child makes her mourn. Her feeling is broken to lose a child, though actually he is looked after by her relative. In the chapter, Seierstad uses mental process a lot to emphasize the readers that as an Afghan mother, Bibi Gul is responsible and affectionate. She cares about her children and remembers their childhood activities which sometimes make her cry.

\section{The Representation of Daughter}

Leila is the character representing a daughter in the novel. In Afghanistan, a daughter is obedient to the mother and eldest brother as shown in the novel. Leila is told as the daughter who has internal conflict. On one hand, she obeys what her family orders in relation to the suitors the family chooses, but on the other hand she has someone else to like. The chapter presenting Leila the most is entitled "A Broken Heart". The title here refers to the passion that Leila has to forget. She wants to have a husband whom she loves, yet she has to consider her family's name. in the novel, Seierstad uses material, mental and relational processes the most to present Leila.

In material process, Leila is also narrated as a daughter who has an internal conflict with herself. The clauses below are the examples.

.....She [Actor] goes to the market [Goal]. Fifteen minutes later [Circ. of time] she returns with a bag of onions [Goal] and is received with suspicion (Seierstad, pp.267-268).

The novel told that girls are forbidden to leave the house alone, including buying things in the market. However, the extract above shows that Leila violates the rule. It is a representation of her internal conflict since she has to hide her feeling toward the man she loves. The representation of Leila as an Actor shows that she has the intention to go to the market and return home. The verb phrase "received with suspicion" is a result of Leila's act.

Actually, Bibi Gul has chosen a suitor for Leila though he is not the man whom she loves. However, Leila shows her obedience to her mother by serving the suitor, Karim. The extract below shows the proof.

The next morning he didn't see her, although she [Actor] had prepared water for him [Goal] to wash in, fried his egg [Goal], and made his tea [Goal]. (p.271) She [Actor] had even polished his shoes [Goal] while he was sleeping [Circ. of time] (Seierstad, p.271).

The extract above involves Leila as the actor marked by the verbs "had prepared", "fried", "made", and "had even polished". Those verbs are related to actions done to the man. It is a woman's responsibility to prepare things to men in the family. As a daughter, Leila shows her responsibility for the sake of her family's name. The suitor is served well by Leila since she does not intend to get a bad image by the suitor if he is not served well. Furthermore, Leila also wants to please her mother as the role of the family how to behave at home.

Despite describing Leila's actions in material process, the author also portrays Leila 
in relational process. The process is to attach Leila to particular Attribute and state. The clauses below are the examples.

She [Carrier] is desperate [Attribute]; a new reality has been forced on her. (p.269)

Her only thought [Carrier] was that the letter writer was in the apartment [Attribute]. (Seierstad, p.271)

For Leila, Karim is like a brother for her. $\mathrm{He}$ is described as a kind and helpful man. Karim is even eager to ask Leila whether she wants to be his wife or not. Khan's family has accepted and welcome Karim as a suitor. Seierstad portrays Leila as a Carrier who is attached to the Attribute "desperate". What makes Leila desperate is that Karim is someone who she respects, too. On the other hand, what makes her heart beat fast is Aimal instead of Karim. In the second datum above, Leila's thought is also attached to the Attribute which refers to Aimal. The use of negation "only" stresses Leila's being attached to Aimal.

Aimal is described as the character who sends letters to Leila. However, Leila never answers the letters since she assumes it as a sin. Leila remembers what happens to Jamila since a man visited her once. The family decides to kill Jamila since she is seen as a disgrace to her family. Similarly, Leila thinks that she bertrays the suitor even though they have not married yet. However, when the family already chooses a suitor, the girl should not have any relation to other men.

Leila [Senser], too, wants to be young and untouched [Phenomenon] (Seierstad, p.273).

In the novel, Seierstad describes Leila as a Senser, the participant who feels. In the first datum above, the mental verb "want to" is categorized into desiderative process. The Senser has particular desire of the Phenomenon. The extract can be interpreted that Leila has awareness not to reply Aimal's letters. She wants to be untouched for the sake of herself and family's dignity.

Another type of relational process to describe Leila is possessive relational process. It is marked by the verb "have". The extract below is the example how Seierstad uses possessive relational process to describe Leila. It was not that Leila [Possessor] had no suitors [Possessed]- she [Possessor] already had three [Possessed]. (Seierstad, p.274)

But she [Possessor] has no feelings toward him [Possessed]. (Seierstad, p.279)
As a possessor, Leila is described to have particular things: suitors and feelings. Leila has not decided her marriage even though she already has three suitors. What is absent is the feeling she has toward the suitors. The use of negation "no" in the second datum above emphasizes that feeling is the most important thing for Leila in a marriage. She does not directly follow Khan's choice of the suitors, but she chooses to nurture her love in loneliness.

The other dominating process is mental process. It refers to the cognition and feeling Leila has. In relation to marriage, what influences Leila is the future she will have after marriage. The story tells that a wife will live in the same house as the husband's parents and siblings. The extract below shows Leila's cognition of marriage.

But Leila [Senser] knew that she would continue to be a servant [Phenomenon]. (Seierstad, p.274) Leila is aware that her life after marriage will not get better. That is, why Leila is described as a Senser. The mental verb "knew" shows Leila's cognition and awareness about her future. The Phenomenon above is presented in a noun clause portraying the life after marriage. This interpretation is emphasized in the following datum.

Leila [Carrier] would remain the servant girl [Attribute]. (Seierstad, p.274)

The clause above is presented in a relational process marked by the verb "remain". Leila is attached to "the servant girl" if she decides to marry one of the suitors. Her life will not get better after marriage. Leila has a dream to have a better life and career. That is the reason why Leila is not married yet.

\section{CONCLUSION}

Afghan women analyzed in this research refer to a wife, mother and daughter. Based on the analysis, those characters are narrated in material processes the most. They are presented as Actors, the characters who conduct material verbs. Women in Afghanistan are represented as submissive and devoted. As a wife, Sharifa keeps her position as a wife even though the husband has another wife. She chooses to remain silent for the sake of family's name since a divorcee is seen as someone disgrace.

Bibi Gul, the mother, is presented as an affectionate mother who cares about her children. She is portrayed as the model of 
mother who loves her children. She also chooses suitors for the children as it is her responsibility. As an old woman, Bibi Gul is also presented in material process, yet it does not refer to her physical activities to take care about households. The material process referring to Bibi Gul is to show her daily activities at home to enjoy her elderly.

As an unmarried daughter, Leila is also presented as a submissive and devoted character to the family. Her submission to bury her feeling is a proof that she submits her future to the family's decision. Furthermore, the material processes taking Leila as the Actor also reveals a devoted daughter since what she conducts is for the sake of family's name and dignity.

This research concludes that the author has different ways to portray different roles of character in a novel. The choice of the process, participants and circumstances results in different interpretation of the characters. This analysis also provides hard data as the proof to support the interpretation of the novel. By means of stylistic analysis, a literary work can be interpreted in an objective way.

\section{ACKNOWLEDGMENT}

This paper is a research product funded by Kopertis Wilayah $V$ Yogyakarta supported by the research and community service institute of Sanata Dharma University under the contract no. 049a/LPPM USD/VI/2018.

\section{REFERENCES}

Andrews, A. (2016). (Re)Defining Afghan Women Characters as Modern Archetypes Using Khaled Hosseini's A Thousand Splendid Suns and Asne Seierstad's The Bookseller of Kabul. ProQuest LLC.

Beard, A. (2004). The Language of Literature. New York: Routledge.

Brooks, J. (2009-2010). The Growing Absurdity of the South African Apartheid: Transitivity in Christopher Van Wyk's "In Detention". INNERVATE, 2, 26-34.

Boukari, N., \& Koussouhon, L. A. (2018, April). Transitivity Analysis of Gabriel Okara's The Voice. International Journal on Studies in English Language and Literature (IJSELL), 6(4), 1-15.

Downing, A., \& Locke, P. (2006). English Grammar: A University Course. London: Routledge.

Ezzina, R. (2015). Transitivity Analysis of The Crying a lot of 49 by Thomas Pynchon. International Journal of Humanities and Cultural Studies, 2(3), 283-293.

Gallardo, B. C. (2006). Analysis of Literary Work Using Systemic Functional Grammar. 33rd International Systemic Functional Congress (pp. 735-762). Sao Paulo: PUCSP, Brazil.

Gee, J. P. (2005). An Introduction to Discourse Analysis: Theory and Method. New York: Routledge.

Gusrayani, D. (2008). Thematic and Transitivity Analysis of Children's Songs and Stories. Jurnal Sastra Inggris, 8(1), 61-75.

Halliday, M., \& Matthiessen, M. (2004). An Introduction to Functional Grammar. London: Horder Arnold.

Halliday, M., \& Webster, J. J. (2009). Continuum Companion to Systemic Functional Linguistics. New York: Continuum. 
Jayal, J. (2013). Stylistic Analysis of Leo Tolstoy's Short Story: God Sees the Truth, but Waits. The Criterion: An International Journal in English (12), 1-9.

Jeffries, L., \& Mclntyre, D. (2010). Stylistics. Cambridge: Cambridge University Press.

Koussouhon, L. A., \& Dossoumou, A. M. (2015). Exploring Ideational Metafunction in Helon Habila's Oil on Water: A re-evaluation and redefinition of African Women's Personality and Identity through Literature. International Journal of Applied Linguistics and English Literature, 4(5), 129-137.

Nguyen, T. H. (2012). Transitivity Analysis of Heroic Mother by Hoa Pham. International Journal of English Linguistics, 2(4), 85-100.

Opara, S. (2012). Transitivity Systems in Selected Narrative Discourse. International Journal of Arts and Commerce, 1(7), 109-121.

Pradnyadari, P. A., Aryawibawa, I. N., \& Rahayuni, N. S. (2018, August). Transitivity of English Verbs in Short Story “Pinnochio”. Jurnal Humanis, Fakultas Ilmu Budaya Unud, 22(3), 633-640.

Rahimi, W. M. (1991). Status of Women: Afghanistan. Bangkok: UNESCO Principal Regional Office for Asia and the Pacific.

Ravassat, M., \& Culpeper, J. (2011). Stylistics and Shakespeare's Language: Transdisiplinary Approaches. New York: Continuum.

Shah, S. K., Zahid, S., Shakir, A., \& Rafique, S. (2014). Representation of Women in Mann O Salwa: A Case Study through Feminist Stylistic Analysis. Research on Humanities and Social Sciences, 4(7), 90-105.

Song, Z. (2013). Transitivity Analysis of a Rose for Emily. Theory and Practice in Language Studies, 3(12), 2291-2295.

Verdonk, P. (2002). Stylistics. Oxford: Oxford University Press. 
LiNGUA Vol. 14, No. 2, December 2019 • ISSN 1693-4725 • e-ISSN 2442-3823 